\title{
Analysis of the cause of crack in a brick structure
}

\author{
Shang Xiang 1, a , Guobo Luo ${ }^{1, b}$,Xuerui Yang1, c \\ ${ }^{1}$ Guizhou Construction Science Research \& Desigh Institute Co. Ltd, Guiyang 550000, China \\ a337198249@qq.com, b745630455@qq.com , ‘xuerui.yang@126.com
}

Keywords: Brick structure,inspection, cracks

Abstract. In recent years, the development of new materials is rapid, and the quality of materials brought by it is also obvious. Based on an engineering example, this paper expounds the process of detection, identification and cause analysis of a brick masonry structure, and provides reference for similar project detection and identification.

\section{Project overview}

A building is a five-layer partial six-layer bottom frame structure. Adopt independent column and strip foundation, the building a layer adopts the frame structure (stairwells for wall bearing), a hybrid structure on the second floor (frame and wall hybrid bearing), three layer and above the wall bearing; The walls of the building are made of sintered brick and high strength waterproof gypsum brick. The first and second floor boards and roof panels are made of cast-in-place and the other floors are prefabricated.

\section{The cause and purpose of inspection}

During the use of the building, the wall is cracked and the principal commissioned my unit to inspect and identify the building to determine the cause of the crack.

\section{Inspection content}

According to the site preliminary view, and according to the client's purpose and related specifications. [1], My unit tested the building for the problems that occurred in the project, and the test contents were set as follows: building vertical degree detection, wall crack and defect detection, wall masonry brick test.

\section{Inspection results}

Building vertical test.J2-2 theodolite is used to measure the vertical degree of the building, According to 《Standard for appraisal of reliability of civil buildings》 (GB50292-2015) ${ }^{[2]}$ for testing 。 According to the test results, the maximum value of the house is $10 \mathrm{~mm}$., According to 《Standard for appraisal of reliability of civil buildings》 (GB50292-2015) 7.3.10, Building tilt limit is. $52.4 \mathrm{~mm}(17300 / 330=45.5)$, The measured inclination maximum is $10 \mathrm{~mm}$, Less than the standard allowable value, the building perpendicularity meets the specification requirement.

Wall crack and defect detection. The maximum crack width of the building was $3.0 \mathrm{~mm}$, and the cracked wall was mainly wet and severe, and the wall was precipitated with white, As shown in figure 1 。 

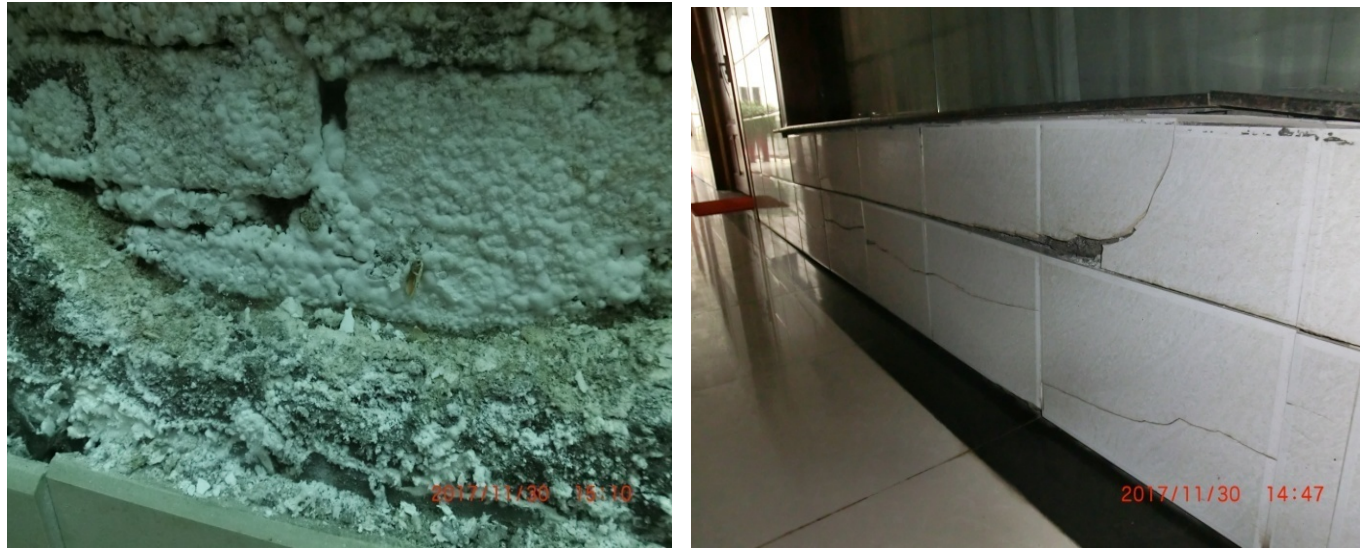

Fig.1 The wall is cracked and white matter precipitates out.

Brick detection of wall masonry.In wall brick specimens from indoor experiment in situ, determine the wall brick of flexural compressive strength, bibulous rate and saturation coefficient, frost resistance, dry shrinkage, softening coefficient, chemical composition analysis, test and burn vector, determine if they meet the relevant and corresponding specification requirements. A group of sintering bricks and two groups of high strength waterproof gypsum tiles were selected for the above index test. The results were as follows: :

Flexural and Compressive strength. (1) According to the results of the test, the compressive strength of ordinary bricks is consistent with the MU15 strength level.(2)According to the test result andQ/KLP-JC001-2008, In the two groups of high-strength water-resistant gypsum tiles, one group of anti-folding and compressive strength conforms to the MU10 strength grade, and one group of anti-folding and compressive strength conforms to the MU15 strength grade.

Water absorption and saturation coefficient.The experimental results of the randomly selected 1 group of sintering bricks and 2 groups of gypsum tiles are shown in table 1 below.

Table 1: Water absorption and saturation coefficient

\begin{tabular}{|c|c|c|c|c|c|c|}
\hline type & $24 \mathrm{~h}$ & $3 \mathrm{~h}$ & \multicolumn{2}{|c|}{$\begin{array}{c}\text { Boil 5h water absorption } \\
\text { rate. }\end{array}$} & \multicolumn{2}{|c|}{$\begin{array}{c}\text { Boiling 5h saturation } \\
\text { coefficient }\end{array}$} \\
\hline \multirow{2}{*}{$\begin{array}{c}\text { Sintered common } \\
\text { brick }\end{array}$} & $15 \%$ & $17.2 \%$ & $\begin{array}{l}\text { The } \\
\text { average }\end{array}$ & $\begin{array}{c}\text { Single block } \\
\text { maximum }\end{array}$ & $\begin{array}{c}\text { The } \\
\text { average }\end{array}$ & $\begin{array}{c}\text { Single block } \\
\text { maximum }\end{array}$ \\
\cline { 4 - 7 } & & $18.7 \%$ & $19.5 \%$ & 0.80 & 0.88 \\
\hline Gypsum brick 1 & $17.6 \%$ & $19.1 \%$ & $17.0 \%$ & $21.4 \%$ & 0.93 & 0.96 \\
\hline Gypsum brick 2 & $15.4 \%$ & $17.0 \%$ & $19.8 \%$ & $20.5 \%$ & 0.94 & 0.96 \\
\hline
\end{tabular}

According to 《Fired common bricks》(GB5101-2003) ${ }^{[3]}$, The water absorption rate and saturation coefficient of ordinary brick are consistent with the index requirements of non-severe weathering zone clay bricks.

With reference to the specification 《Fired common bricks》(GB5101-2003) 5.4 provisions, The average value of the saturated coefficient of the high-strength water-resistant gypsum brick is greater than 0.88 , the maximum value of the single block is greater than 0.9 , and the resistance of the brick is not satisfied, and the anti-freezing test should be done.

Frost resistance.According to the results of the test, the index of freezing-thawing of ordinary bricks is in accordance with the requirements of 《Fired common bricks》 (GB5101-2003), and the indexes of freeze-thaw test are qualified. The test specimen of gypsum brick in the freezing-thawing test was obviously damaged, and the freeze-thaw test was not qualified. 
Drying shrinkage.According to the test results, the drying shrinkage value of ordinary brick is $0.040 \mathrm{~mm} / \mathrm{m}$ 。 The drying shrinkage value of gypsum brick is $0.042 \mathrm{~mm} / \mathrm{m}$, To achieve 《High strength wateresisted gypsum bricks》 (Q/KLP-JC001-2008) ${ }^{[4]}$, The requirement of the superior product meets the specification requirement 。

Softening coefficient.According to Q/KLP-JC001-2008, In the two groups of high-strength water-resistant gypsum tiles, the softening coefficient of one group was 0.94 , and the other group was 0.85 , all greater than 0.75 , meeting the standard requirements.

Chemical composition analysis and burning vector.Three groups of gypsum bricks and 1 group of sintering bricks were extracted for chemical composition analysis, and the mean values of the three groups of bricks were shown in table 2 . The results of sintering brick are shown in table 3 .

Table 2 Chemical composition average of three groups of gypsum tiles

\begin{tabular}{|c|c|c|c|}
\hline The test items & Test results & The test items & Test results \\
\hline$\omega\left(\mathrm{S}_{\mathrm{i}} \mathrm{O}_{2}\right) \%$ & 25.20 & $\omega\left(\mathrm{Na}_{2} \mathrm{O}\right) \%$ & 0.57 \\
\hline$\omega\left(\mathrm{Fe}_{2} \mathrm{O}_{3}\right) \%$ & 0.55 & $\omega(\mathrm{CaO}) \%$ & 40.83 \\
\hline$\omega\left(\mathrm{Al}_{2} \mathrm{O}_{3}\right) \%$ & 2.48 & $\omega(\mathrm{MgO}) \%$ & 1.76 \\
\hline$\omega\left(\mathrm{TiO}_{2}\right) \%$ & 0.32 & $\omega\left(\mathrm{SO}_{3}\right) \%$ & 25.32 \\
\hline$\omega\left(\mathrm{P}_{2} \mathrm{O}_{5}\right) \%$ & 2.31 & $\omega($ loss on ignition $) \%$ & 13.29 \\
\hline$\omega\left(\mathrm{K}_{2} \mathrm{O}\right) \%$ & 0.65 & - & - \\
\hline
\end{tabular}

Table 3 Chemical composition analysis and test results of sintering brick

\begin{tabular}{|c|c|c|c|}
\hline The test items & Test results & The test items & Test results \\
\hline$\omega\left(\mathrm{S}_{\mathrm{i}} \mathrm{O}_{2}\right) \%$ & 50.14 & $\omega\left(\mathrm{Na}_{2} \mathrm{O}\right) \%$ & 0.40 \\
\hline$\omega\left(\mathrm{Fe}_{2} \mathrm{O}_{3}\right) \%$ & 11.00 & $\omega(\mathrm{CaO}) \%$ & 1.13 \\
\hline$\omega\left(\mathrm{Al}_{2} \mathrm{O}_{3}\right) \%$ & 60.65 & $\omega(\mathrm{MgO}) \%$ & 1.60 \\
\hline$\omega\left(\mathrm{TiO}_{2}\right) \%$ & 1.21 & $\omega\left(\mathrm{SO}_{3}\right) \%$ & 0.64 \\
\hline$\omega\left(\mathrm{P}_{2} \mathrm{O}_{5}\right) \%$ & 0.24 & $\omega\left(\mathrm{M}_{n} \mathrm{O}_{3}\right) \%$ & 0.31 \\
\hline$\omega\left(\mathrm{K}_{2} \mathrm{O}\right) \%$ & 2.68 & $\omega$ (烧失量 $) \%$ & 2.62 \\
\hline
\end{tabular}

According to the above test results, the chemical composition analysis of this batch of high-strength water-resistant gypsum bricks is, $\mathrm{SiO}_{2} 、 \mathrm{Te}_{2} \mathrm{O}_{3} 、 \mathrm{Al}_{2} \mathrm{O}_{3}$ The content of the active mixture is low 。 he average content of $\mathrm{CaO}$ in 3 groups was $40.83 \%$, and the content of sintering brick was $0 \% \sim 15 \%$. The average content of SO3 in the three groups of gypsum bricks was $25.3 \%$, the content of sintering bricks was $0 \% \sim 3 \%$, and the content of gypsum brick $\mathrm{CaO}$ and $\mathrm{SO} 3$ was much higher than that of sintering brick. To sum up, the indexes of sintered ordinary bricks meet the standard requirements; The anti-freeze (freeze-thaw test) of the high strength waterproof gypsum brick is not satisfied. According to the article 8.4.4 of Q/ klp-jc001-2008 ${ }^{[4]}$, the gypsum brick is not qualified. According to the results of chemical analysis, the $\mathrm{CaO}$ and $\mathrm{SO} 3$ content of gypsum brick is much higher than that of sintering brick. 


\section{Crack analysis}

Settlement crack, bearing capacity crack. The vertical degree of the building meets the requirements of the specification. The characteristics of the wall cracks are not in accordance with the stress cracks and bearing capacity cracks, and the cracks of the building wall are excluded as settlement cracks and force cracks.

Expansion and shrinkage cracks.through on-site inspection, the position of the serious USES horizontal cracks Gao Jiangnai water gypsum brick or gypsum mixed with baked brick masonry, cracks are part of the foundation, wall in the bathroom wall, kitchen window sill have water or wet areas, such as dry wall does not appear obvious horizontal crack, thus the water is the cause of the problem above.

Gao Jiangnai gypsum brick, water is the dihydrate gypsum (CaSO4 $\bullet 2 \mathrm{~h} 2 \mathrm{o})$, the water rigid gelled material as the main raw material, after blank preparation, forming and steam curing is main wall made of building gypsum products, exciting agent is added in production (such as: yellow phosphorus slag, fly ash, lime, etc.). In the humid environment, water enters the inside the brick, easy CaSO4 combine with water to regenerate the $\mathrm{CaSO} 4 \cdot 2 \mathrm{~h} 2 \mathrm{o}$, phosphorus gypsum brick after absorbing water volume expansion, will produce larger expansion stress, lower the adhesive strength of mortar and brick, and generate along the horizontal crack of mortar joint. At the same time, CaSO4 and MgSO 4 are slightly soluble in water, and as the water evaporates, the white crystals are precipitated on the surface of the brick and there is a frosting phenomenon. The physical and chemical changes of high-strength water-resistant gypsum bricks and water are long-term cycles, and physical and chemical changes will occur as long as the water is in contact with CaSO4 in gypsum tile.

Known from the analysis of the above, the building wall ceramic tile burst, horizontal cracks and the cream of the brick surface is mainly Gao Jiangnai water gypsum brick produced under the influence of water lead to the results of physical and chemical changes.

Temperature crack.Main cracks in the Windows and doors mouth of diagonal, horizontal crack roof board and wall body junction, outside the top end longitudinal wall inclined cracks, the top cross wall and outer wall junction inclined cracks, horizontal or diagonal crack of the western wall. Some cracks in this project are such cracks.

\section{Conclusion}

1) There are many cracks in the masonry wall. After the cracks in the building, the cracks should be tested according to the characteristics of the cracks, and the reasons for the cracks are determined;

2) In recent years, there are many new materials, and the quality of materials should be taken seriously.

\section{References}

[1] 《Technical standard for inspection of building structure》(GB/T 50344-2004);

[2] 《Standard for appraisal of reliability of civil buildings》(GB50292-2015);

[3] 《Fired common bricks》(GB5101-2003);

[4] 《High strength wateresisted gypsum bricks》(Q/KLP-JC001-2008). 